\title{
NATURAL OCCURRENCE OF BACULOVIRUSES IN POPULATIONS OF SOME HELICONIINI (LEPIDOPTERA; NYMPHALIDAE) WITH SYMPTOMATOLOGICAL NOTES
}

\author{
C. F. S. ANDRADE \\ M. E. M. HABID
}

\begin{abstract}
Natural occurrence of nuclear polyhedrosis viruses were detected in populations of some Heliconiini in the field as well as in the laboratory. The epizootics appeared under field conditions in populations of Dione juno juno, D. moneta and Agraulis vanillae maculosa. In the laboratory, however, larvae of Heliconius numata mirus, $\mathrm{H}$. hecale vetustus and $\mathrm{H}$. erato phyllis in addition to two hybrids and Eueides isabella dianasa, all suffered the same disease.

The effect of several factors which might contribute to the occurrence of the disease are discussed. Symptoms, histopathology and description of viral particles and polyhedra are given.
\end{abstract}

\section{INTRODUCTION}

Baculovirus diseases in insects are well known, principally among lepidopterous and hymenopterous species (Martignoni \& Langston, 1960; Steinhaus \& Marsh, 1962; Poinar \& Thomas, 1978). Also, mode of action, symptoms and histological alterations of nuclear polyhedrosis diseases have been reported by many authors, such as Aizawa (1963), Bulla (1973), David (1975), Andrade (1981) and Andrade et al. (1978).

Within the Nymphalidade, nuclear polyhedrosis viruses (NPV) have been recorded in Aglias urticeae (L.) (Breed \& Petraitis, 1954 and Smith \& Xeros, 1955), Polygonia satyrus Edw. (Steinhaus \& Marsh, 1962), Vanessa cardui (L.) (Balch, 1958; Neilson \& Marks, 1956 and Smith, 1954) and Junonia coenia Hbn. (Steinhaus, 1958). The first two genera occur in Europe, Asia and North America, while the last two are cosmopolitan (Watson \& Whalley, 1975).

New World heliconian species are mainly tropical, although some are distributed in subtropical regions. This group, according to Brown (1979) and Brown \& Mielke (1972), is characterized by some mimetic complexes and is highly convenient for genetic, ecological and evolutionary studies.

This contribution forms part of a study designed to find out more about the natural occurrence of viral diseases among insects in Brazil

Departamento de Zoologia, Instituto de Biologia, Universidade Estadual de Campinas, 13.100 Campinas, SP. 
and their possible utilization in microbial control programs. This paper treats with a NPV disease occurring naturally in some heliconian species in the field as well as under laboratory conditions, and presents symptomatological analyses.

\section{MATERIAL AND METHODS}

Field observations were conducted in populations of Dione juno juno and Agraulis vanillae maculosa, both attacking Passiflora biflora Lam., 1789 leaves. This plant species was introduced from Panama and cultivated by Dr. W. W. Benson, in order to maintain cultures of some Heliconiini, necessary for genetic and evolutionary investigations. Other observations were undertaken in populations of $D$. moneta under field conditions. The laboratory studies, however, were carried out with larvae of A. vanillae maculosa, D. juno juno, Heliconius hecale vetustus, $H$. numata mirus and Eueides isabella dianasa. Two hybrids, H. erato phyllis $\mathrm{x} H$. erato venustus and $H$. erato amalfreda, were also used during the laboratory investigations.

Daily temperatures and relative humidity records were obtained during the investigations. Histological sections $6-8 \mu \mathrm{m}$ thick were obtained from larvae representing different stages of the disease course. Normal histological and staining techniques were used.

Purified polyhedra were obtained by a three-step differential centrifugation $(3,000 \mathrm{~g} / 15 \mathrm{~min}, 1,000 \mathrm{~g} / 10 \mathrm{sec}$, and $2,000 \mathrm{~g} / 10 \mathrm{~min})$ of diseased tissues suspended in water at $\mathrm{pH}$ 6-7 (adapted from Bergold, 1953).

For liberation and obtaining of the viral particles, the polyhedra were disolved at room temperature during approximately two hours, with occasional gentle shaking in $0.03 \mathrm{M}$ sodium carbonate $+0.05 \mathrm{M}$ sodium chloride (adapted from Harrap et al., 1977 and Steinhaus, 1963). The opaque suspension was then centrifuged for 6 minutes at $3,000 \mathrm{~g}$. The supernatant was centrifuged at $10,000 \mathrm{~g}$ for one hour, giving the virus as sedimented particles.

A Zeiss-9-S2 electron microscope was used for histopathological observations, viral description and photography.

\section{RESULTS AND DISCUSSION}

\section{A. Incidence of NPV disease}

During October and November, 1979, cultures of four species and two hybrids of Heliconiini suffered a high mortality due to virus disease in the insectary of Dr. W. W. Benson, Dept. of Zoology, UNICAMP. Temperature and relative humidity averaged $31.5^{\circ} \mathrm{C}(\max ),. 22.5^{\circ} \mathrm{C}(\min$. and $\mathbf{7 2 . 5 \%}$ R.H. during the disease manifestation. Under these laboratory conditions, in addition to general investigations among these heliconian species, the present authors observed a culture of $D$. juno juno. This culture, composed of 175 individuals, suffered a $100 \%$ mortality within 
15 days. $72.3 \%$ of mortality was observed among the last three larval instars (details in Fig. 1).

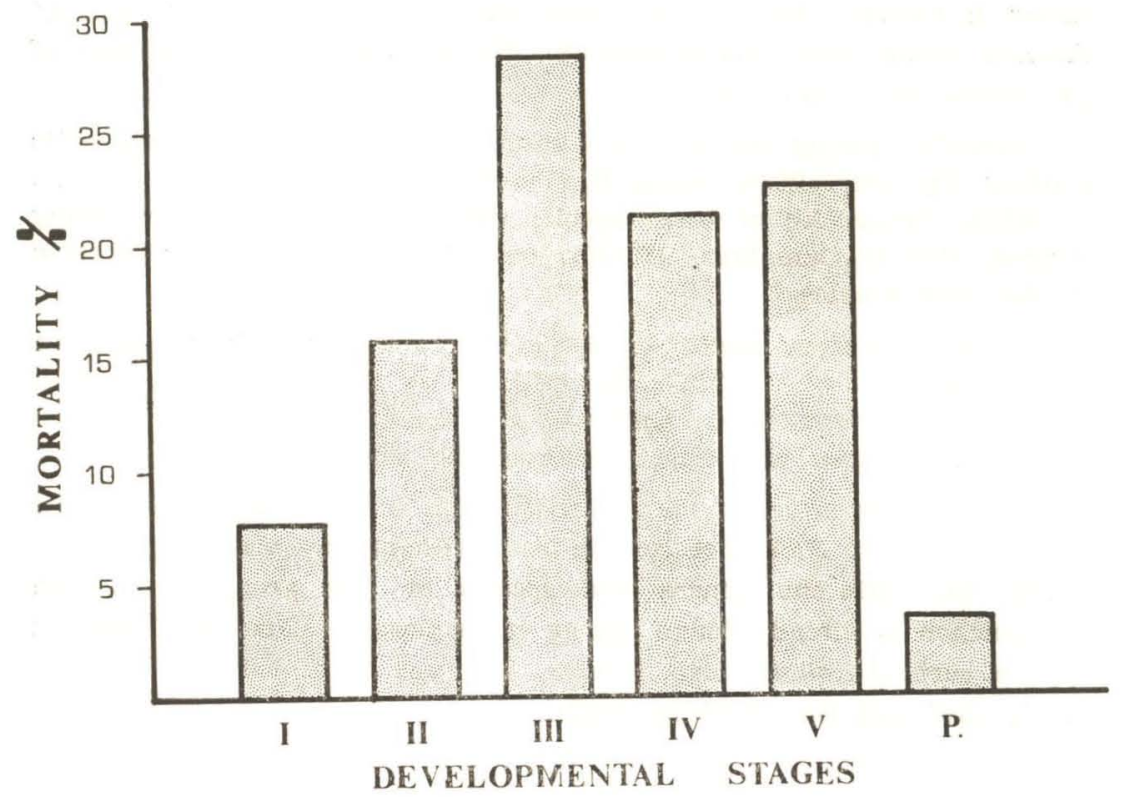

Fig. 1 - Mortality during the different larval instars and pupal stage of $D$. juno juno, caused by NPV infection under laboratory conditions.

D. juno juno, A. vanillae maculosa and $H$. erato phyllis are normally distributed in Southeastern Brazil. However, H. erato amalfreda and $H$. hecale vetustus occur only in the north of the Amazon River, while $H$. erato venustus and $H$. numata mirus are distributed in Bolivia and the west of Mato Grosso, Brazil (Brown, 1979).

In the field, Passiflora biflora, cultivated as a food source for insectary breeding, was attacked by $D$. juno juno and $A$. vanillae maculosa. Also, high mortality caused by virus disease was observed under field conditions among populations of these species.

There are some possible factors that contribute to the high incidence of polyhedroses in the two sites mentioned above. As $P$. biflora is not considered as a natural host for $D$. juno juno and A. vanillae maculosa, the leaves of this plant could possibly stimulate latent infection in one or both of these two species in the field, causing death and consequently contaminating the foliage with polyhedra. These contaminated leaves could serve, in the insectary, as a source of infection provoking the observed 
high mortality. Normally, low incidence of virus disease was observed when these two heliconian species attack one of their natural hosts, such as $P$. edulis Sins., commonly distributed in the State of São Paulo. This proposition can be supported by many authors who mentioned that alterations in diets increase the incidence of NPV diseases (Vago \& Cayrol, 1955; Bergold, 1958; Kovacevic, 1954 and 1956). However, Steinhaus \& Dineen (1960) stated that alteration in the natural diet of Junonia coenia Hbn. (Nymphalinae) did not modify the incidence of granulosis virus (GV) diseases.

Recently, during our periodical survey, we observed a viral epizootic causing high mortalities among $D$. moneta, $D$. juno juno and $A$. vanillae maculosa larvae. All of these species were attacking $P$. edulis during August, 1982 in Campinas, SP. However, higher incidence was detected in the first species.

Under laboratory conditions, Eueides isabella dianasa larvae suffered $100 \%$ mortality when artificially infected by the NPV isolated from diseased D. moneta larvae. Under natural conditions, only one pupa of $E$. isabella dianasa was found suffering the same disease.

All of these informations reveal the high susceptibility of this tribe to a complex of NPV diseases, at least without any visible specificity within the different genera and species of this group. The same phenomenon is already found among some closely related lepidopterous species, such as Heliothis spp. (Stairs, 1971) and Spodoptera spp. (Harrap et al., 1977 and Bud \& Kelly, 1977).

\section{B. Pathology and viral description}

The course of the disease observed in the present work among the heliconian species was generally typical of nuclear polyhedral infections of other Lepidoptera (Steinhaus, 1958; Aizawa, 1963; DeBach, 1964 and Poinar \& Thomas, 1968). Loss of appetite and sluggishness in movement were observed. The diseased larvae migrated to the top of the host plant or the cages and died in a hanging position. D. juno juno larvae lost their gregarious habit; similar behavior was observed by Smirnoff (1960) in diseased sawfly larvae and by Andrade (1981) in diseased cotton leafworm, Alabama argillacea. Black markings were observed on the integument of A. vanillae maculosa and Heliconius spp. (Fig. 2, A, B, C and D). The larvae became flaccid, the skin disrupted easily and the turbid hemolymph flowed out. Death occurred within 10 to 15 days.

Histopathological examinations of larvae in early stages of infection showed hypertrophy of the fat body nuclei. Presence of polyhedra in cells of adipose tissue (Fig. 2, E), hypodermis, tracheal epithelium (Fig. 2, F) with chromatin agregation was observed. In heavily diseased larvae, shrinkage and detachment of the hypodermis from the cuticle were visible (Fig. 3, A). Disrupted fat tissue liberated polyhedra and started cytoplasmic breakdown. Hemocytes were heavily infected and 


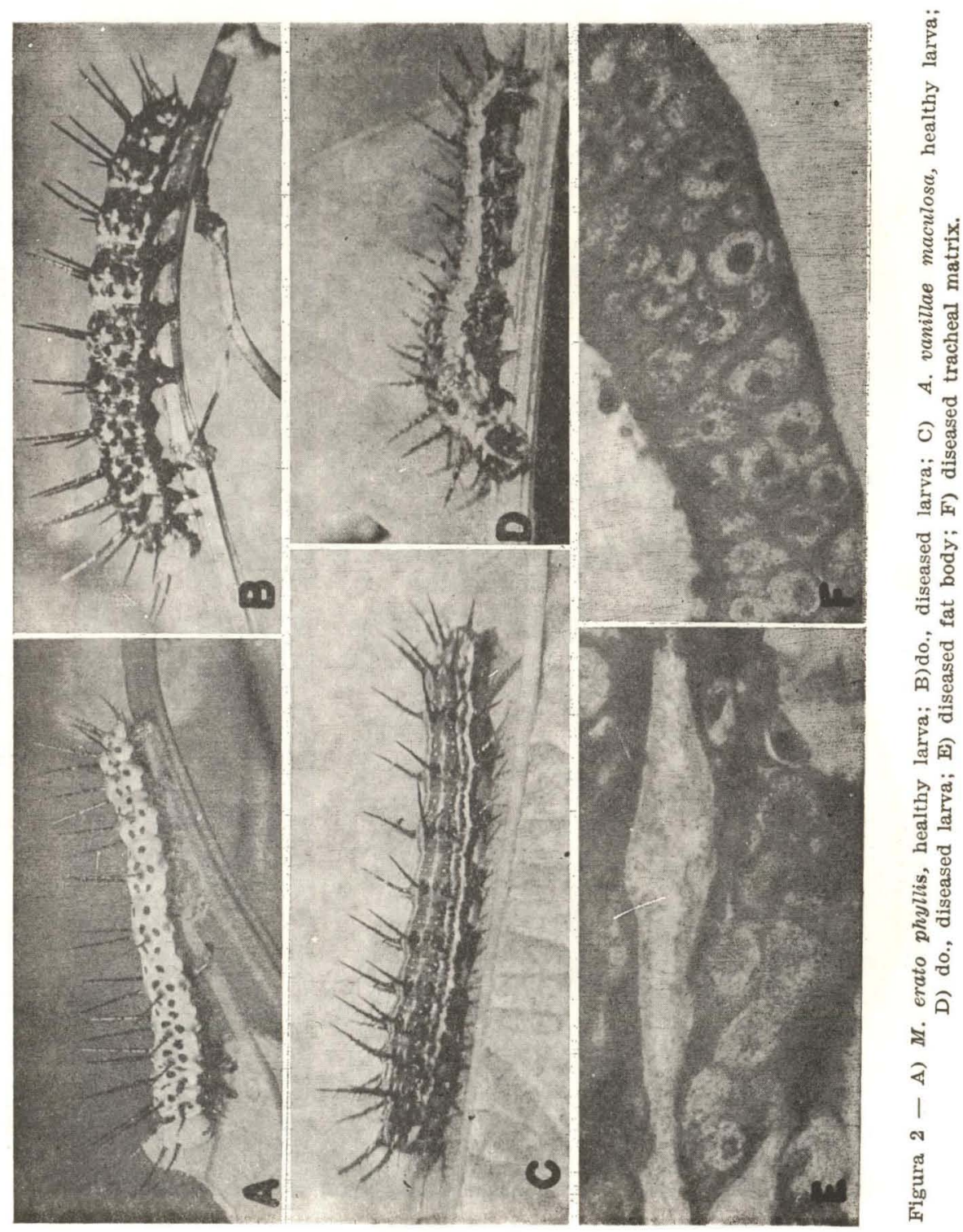



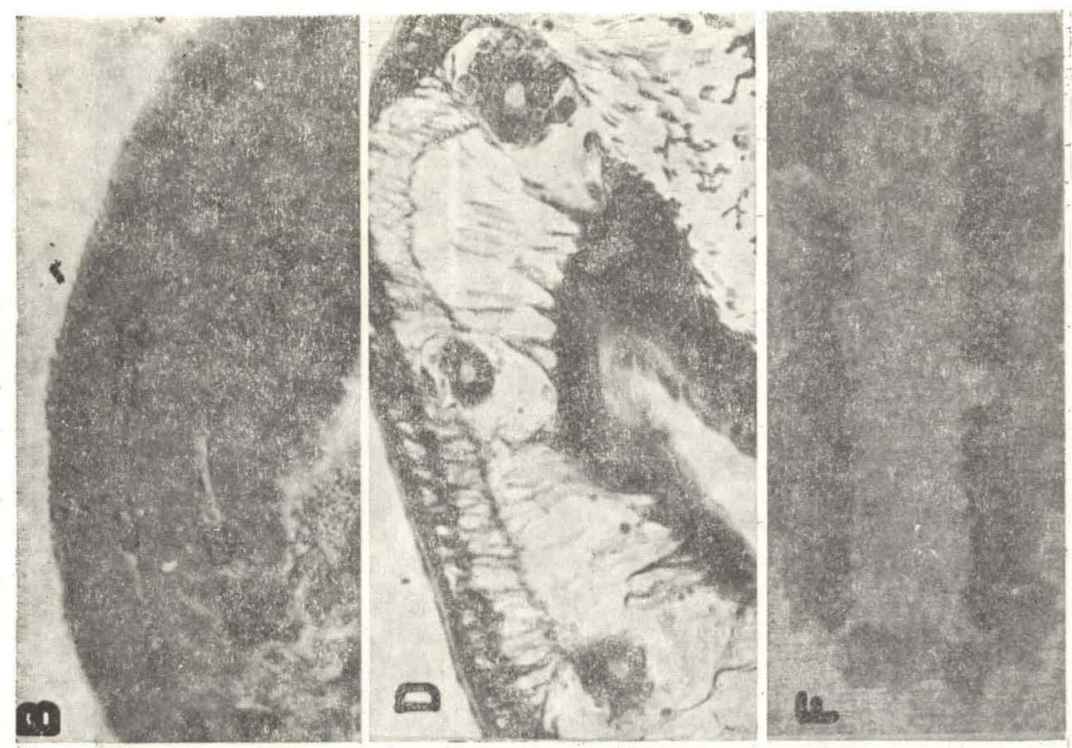

范

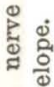

สี

흐욜

ฮึ

敢

ช营

范毛

है..

를
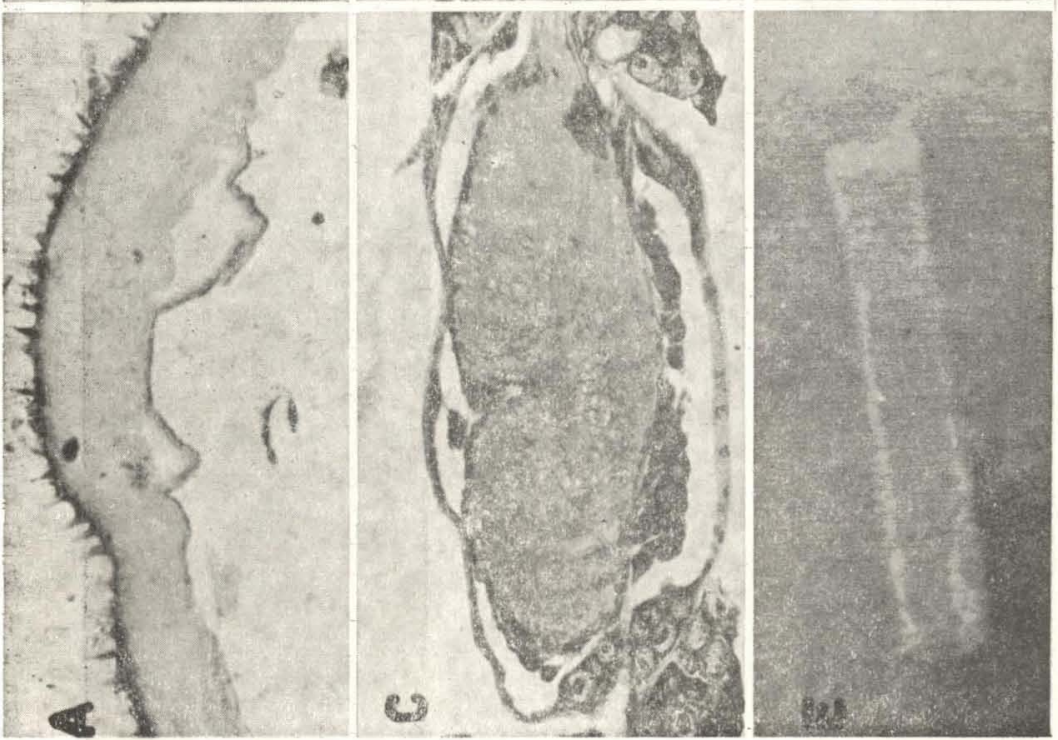

घี

해유

。

न

คิ ฮี

i。

हू

응

究哭

'

ซึ

:

४ิ

।

๓

突 
the intestinal peritrophic membrane was completely disintegrated. Side effects were detected among some tissues, such as muscles, ventral nerve ganglia, wing buds and mid-gut epithelial cells. Concerning the muscular fibres, loosening of fibrillae, disintegration of sarcolemma and cracking in all directions (Fig. 3, B) were observed. The muscular nuclei showed hypertrophy, but polyhedra were not present. The ventral nerve ganglia, in heavily diseased individuals, showed separation between nerve cells and neuropile (Fig. 3, C). The latter was broken down in many positions. Chromatin clumping and neurolemma disintegration were detected. However, no presence of polyhedra was observed. The wing buds also showed some histological alterations, principally total disruption of nuclei (Fig. 3, D) and cytoplasmic destruction. Histopathological details can be found in Figs. 2 and 3 ).

Electron microscopic examination showed that the purified polyhedra obtained from diseased $D$. juno juno larvae measured an average of 0.8 $\pm 0.22 \mu \mathrm{m}$ in diameter. The purified particles of the same source measured an average of $233 \mathrm{~nm}$ in length and 44.14 in width (Fig. 3, E). However, the particles within the envelope are somewhat larger (Fig. 3, F).

\section{REFERENCES}

Aizawa, K., 1963. The nature of infections caused by Nuclear Polyhedrosis viruses, pp. 381-412, in E. A. Steinhaus, ed., Insect Pathology. An advanced treatise 1. Academic Press, New York.

Andrade, C. F. S., 1981. Estudos ecológicos e patológicos de poliedrose nuclear de Alabama argillacea (Hübner, 1818) (Lepidoptera, Noctuidade), 153 pp. Tese de Mestrado, Universidade Estadual de Campinas.

Andrade, C. F. S., J. Lauritis \& M. A. Garcia, 1978. Ocorrência de poliedrose nuclear em larvas de Spodoptera frugiperda (Abbot \& Smith, 1797). Res. III Congr. latino-am. Ent.: 48.

Balch, R. E., 1958. Control of forest insects. A. Rev. Ent. s: 449-468.

Bergold, G. M.; 1953. Ueber Polyeder Krankheiten bei Insekten. Biol. UentBlatt 63: $1-55$.

Bergold, G. H., 1958. Viruses of insects, pp. 60-142, in C. Hallauer \& K. F. Meyer, ds., Handbuch der Virusforschung 4. Springer Verlag, Berlin \& New York.

Breed, R. S. \& A. Petraitis, 1954. Some Russian contributions to taxonomy and nomenclature of the viruses. A review. Int. Bull. Bact. Nom. Taxon. 4: 189-214.

Brown, K. S., Jr. \& O. H. H. Mielke. The Heliconians of Brazil (Lepidoptera: Nymphalidae). Part II. Introduction and general comments, with a supplementary revision of the tribe. Zoologica, N. Y. 57: 1-40.

Brown, K. S., Jr., 1979. Ecologia geográfica e evolucão nas florestas neotropicais, 265 pp. Tese de Livre-Docência, Universidade Estadual de Campinas.

Bud, H. M. \& D. C. Kelly, 1977. The DNZ contained by Nuclear Polyhedrosis viruses isolated from four Spodoptera spp. (Lepidoptera, Noctuidae); genome size and configuration assessed by electron microscopy. J. Gen. Virol. 37: 135-143.

Bulla, L. A., 1973. Regulation of insect populations by microorganisms. Ann. N. Y. Acad. Sci. 217: 1-243.

David, W. A. L., 1975. The status of viruses pathogenic for insects and mites. A. Rev. Ent. 20: 97-117.

DeBach, P., 1964. Control biol6gico de las plagas de insectos y malas hierbas (2. ed.,), 949 pp. Editorial Continental, México, España, Argentina y Chile. 
Harrap, K. A., C. Payne \& J. S. Robertson, 1977. The properties of the baculoviruses from closely related hosts. Virology 79: 14-31.

Kovacavic, Z., 1954. Znacaj poliedrije za basovnu pojavu nekih insekta. Zasht. Bilja 23: $3-20$.

Kovacevic, Z., 1956. Die Nahrungswahl und das Auftreten der Pflanzenschädlinge. Anz. SchädlingsKde 29: 97-101.

Martignoni, M. E. \& R. L. Langston, 1960. Supplement to an annotated list and bibliography of insects reported to have virus diseases. Hilgardia 30 : 1-40.

Neilson, M. M. \& D. B. Marks, 1956. Laboratory trials of an introduced polyhedral disease from larvae of the painted lady butterfly (Vanessa cardui L.) against larvae of the European winter moth (Operophtera brumata L.) and the fall cankerworm (Alsophila pometaria Harr.). Inter. Rep. Can. Dep. Agric. 1955: $1-11$.

Poinar, G. O., Jr. \& G. M. Thomas, 1978. Diagnosis manual for identification of insects pathogens, 218 pp. Plenum Press, New York \& London.

Smirnoff, W. A., 1960. Observations on the migration of larvae of Neodiprion swanei Midd. (Hymenoptera, Tenthredinidae). Can. Ent. 92: 957-958.

Smith, K. M., 1954. Viruses and the control of insect pests. Discovery 15: 455-458.

Smith, K. M. \& M. Xeros, 1955. Cross inoculation studies with polyhedral viruses. Summ. 6 Congr. int. Microbiol., Roma: 185-186.

Stairs, G. R., 1971. Use of viruses for microbial control of insects and mites, pp. 97-124, in H. D. Burges \& N. W. Hussey, eds., Microbial control of insects and mites. Academic Press, London \& New York.

Steinhaus, E. A., 1958. Stress as a factor in insect diseases. Proc. 10, int. Congr. Ent., Montreal 4: 725-730.

Steinhaus, E. A., 1963. Insect pathology. An advanced treatise, 2 vols. Academic Press, New York \& London.

Steinhaus, E. A. \& J. Dineen, 1960. Observations on the role of stress in a granulosis of the variegated cutworm. J. Ins. Pathol. 2: 55-65.

Vago, C. \& C. R. Cayrol, 1955. Une virose à polyèdres de la noctuelle gamma, Plusia gamma L. Ann. Épiphyt. (C) 6: 421-432.

Watson, A. \& P. E. S. Whalley, 1975. The dictionary of butterflies and moths, 296 pp. MacGraw-Hill Book Coo., New York. 